\title{
WHAT'S IN A MESSAGE? ANALYSIS OF ANNUAL GRADUATION MESSAGES IN THE PHILIPPINES
}

\author{
Jeremy Velasquez Basilio \\ Department of Education - Angeles City, Angeles City, Pampanga, Philippines \\ jeremy.basilio@deped.gov.ph \\ IneroValbuena Ancho \\ Philippine Normal University, Manila, Philippines \\ ancho.iv@pnu.edu.ph \\ Gilbert Santos Arrieta \\ Don Bosco Technical Institute, Makati City, Philippines \\ arrieta.gs@pnu.edu.ph
}

\begin{abstract}
What common themes may be derived from annual graduation messages? This inquiry generally informed this study as annual graduation messages issued by the Philippine Department of Education (DepEd) Secretary are analysed. This paper hopes to contribute to a research-based, logical, and relevant crafting of graduation messages in the future. This paper recognizes the impact of each graduation message as it serves as a venue in capturing what DepEd attempts to relay to its stakeholders, particularly student graduates in the context of this paper. This study is anchored on J. L. Austin's Speech Act Theory which claims that "language goes beyond saying but doing things" (Anderson, 2018). Words and utterances serve more than just communication elements as messages but also to convey "propositional truths and assertions". This study employed qualitative method through content analysis using data available online. This study utilized summative content analysis following content or guide words (key words) which eventually led to the reading and understanding of essential and applicable setting. Graduation messages annually issued by DepEd are posted and accessible through online resources. Graduation messages issued from 2010-2019 were utilized in this study. Careful analysis of data revealed the following clustered themes: quality education as the key to transformation, education at the core of life's challenges, Filipino learners transforming the future, stakeholders and learners towards a better education, and K-12 curriculum as the vehicle for success. It was concluded that through annual graduation messages, recognition has been given to stakeholders who play crucial roles in the education system and advocate its success. Also, social, cultural, and curricular aspects have also shaped how each graduation message is crafted and relayed to stakeholders.
\end{abstract}

Keywords: content analysis, education, graduation, graduation messages, Philippines

\section{A. INTRODUCTION}

$\mathrm{n}$ academic graduation is a milestone celebrating success among stakeholders. It
signifies satisfactorily completing requirements that lead to awarding a particular degree,
diploma, or certificate. According to Zaff, et al. (2017), high school education is the youth's preparation to economic and civic affairs involvement. Official graduation ceremonies are 
Velasquez, Ancho, Arrieta, What's in A Message? ...

planned in such a way that these reflect the fruits of labour in forms of studying, taking examinations, submitting class requirements, and writing researches. Challenges are faced by students, however, as graduation rates increase, students also struggle at the required competencies (Bromberg and Theokas, 2016).

Various practices around the world are being observed to mark the end of an academic journey. While a simple and solemn event could capture the meaning and value of graduation ceremonies, grand and extravagant exercises are also observed by some. Graduation may come in various forms and celebration. Fjær, Pedersen, \& Sandberg (2016) even did an inquiry on Norwegian high school graduation celebration parties. Lomsky - Feder (2012) looked as Israeli graduation ceremonies are rooted from "competing intergenerational models of the social order."

Charmatz (2017) refers to graduation as a celebration for students, family, and friends. Students consider graduation as a starting point to either higher level or learning or even employment. Each ceremony is filled with remarkable events as official announcement of graduation is declared. Graduates are presented in academic gowns (Muir \& Palmer, 2019) and are individually called on stage to personally receive their certificates. Teachers are also present in the graduation ceremonies as one of the forerunners of pedagogical approaches in the quest for academic achievement. A study by Robinson, et al. (2017) argued that instituted mechanisms impact high school graduation and dropout. Advocating learning experiences and hands-on competencies result into "a more collective career-related experience and employability skills" (Garcia - Aracil, Monteiro, \& Almeida, 2018). Parents take part in graduation ceremonies as witnesses and partners in recognition of their contribution. Other stakeholders, school officials, and community leaders are also invited in the ceremonies which highlight the positive outcomes of school-community partnerships and multi-stakeholder engagement. Various governmental programs are launched, such as conditional transfers, livelihood training, and others, aim at "graduating people out of poverty" (Roelen, 2020).

To extend congratulatory remarks, varied strategies are employed such as gift-giving, congratulatory remarks, and any other means of celebrating success. To put graduation triumph and challenges into words, numerous graduation messages are written and prepared. These messages come in various forms, either written in the invitation or read during the actual ceremonies. Rohmaniyah and Woodward (2012) looked at the connection of graduation 


\section{Volume 6, Number 1, June 2020}

ceremonies and the systems associated to it and how these shape one's personal and civil character. Congratulatory addresses highlight the recognition of stakeholders' efforts in the light of students' success. These messages look at the past years of struggles and hardships along with a futuristic view of what awaits the graduates in the future.

While preparation and delivery of graduation messages may seem to be a formality gesture, its content and impact cannot be undermined. It captures how the sender puts insights into words, given the nature of education experiences the students went through over the past years. It also serves as a challenge to stakeholders who earnestly work hand in hand to help students reach academic success. Lastly, it provides direction and meaning relative to identified annual theme of the graduation.

In the Philippines, graduation messages are annually prepared by the Secretary of the DepEd for the graduates of public and private basic education curriculum. These annual addresses consist of an average of 300-350 words, which are then relayed to schools all over the country. While there is only one graduation message issued by DepEd per year, education and community leaders also sometimes send their graduation messages. The governor of the province, lawmakers, city mayor, schools district supervisor, and others may also prepare their own address for the graduates who belong to their jurisdiction. These messages may come in form of greetings, challenge to the graduates or invitation to transform the society while banking on what has been learned by the students.

What common themes may be derived from annual graduation messages? This inquiry generally informed this study as annual graduation messages issued by the Philippine Department of Education (DepEd) Secretary are analysed. This paper is an attempt to analyse annual graduation messages with the hope that this would contribute to a research-based, logical, and relevant crafting of graduation messages in the future. The researchers attempted to look at the content of each graduation message as a result of qualitative analysis. The gist of the message serves as inputs in identifying themes of annual graduation message.

This study is anchored on J. L. Austin's Speech Act Theory which claims that "language goes beyond saying but doing things" (Anderson, 2018). Words and utterances serve more than just communication elements as messages but also to convey "propositional truths and assertions". While a typical annual graduation message contains more or less 300 words, it actually tries to 
convey more than what limited sentences and paragraphs would attempt to relay. Using Speech Act Theory as spring board of discussion for analysing graduation messages provides avenues for identifying how DepEd projects the image of the institution in relation to education stakeholders. Moreover, these also send out strong message to students and parents in the midst of graduation celebration: what happens next, what the ceremonies mean, and how the past impacts future endeavour positively.

This paper recognizes the impact of each graduation message as it serves as a venue in capturing what DepEd attempts to relay to its stakeholders, particularly student graduates in the context of this paper. This study places its significance in reporting findings of analysis of annual graduation messages. While these messages are typically seen to be just a part of a formal academic exercise, its impact should be recognized and given emphasis. Through this study, the researchers hope to contribute to the level of education discourses and practices. It is also of equal importance to note how the results of the study could serve as inputs in crafting future graduation messages in terms of focus, approaches, and styles.

\section{B. LITERATURE REVIEW}

Majority of studies conducted related to school graduation pertains to success rate and interventions. Research experts have explored contributing factors that lead to increased graduation rates. Sublett and Rumberger (2018) in a policy study opined that "inaccurate and incomplete" reporting of graduation data puts efforts of improving graduation data into question. Also, the "one-size-fits-all" strategy for school effectiveness was also scrutinized. Wills, et al. (2017) have recognized how Career Technical Education relates to "higher graduation outcomes, controlling for academic, behavioural and demographic factors" which eventually impact graduation. It has also been hypothesized that "maltreated youth's connectedness" create a positive bearing on graduation (Lemkin, et al., 2018). It could be gleaned from these attempts that strategies leading to graduation success are varied and outcomes of these efforts are deemed unpredictable, if not unexpected.

Graduation as a milestone and what comes after this timeline has been explored by numerous authors. Arcidiacono, et al. (2016) concluded that those students who belong to minority groups in the areas of science, technology, and mathematics "took longer to graduate." Students' involvement in undergraduate research has also been instrumental in successfully earning a degree (Rodenbusch, et al., 2016). It appears that the focus of researches focusing on graduation generally revolves around successful conferment of academic degree or related factors 


\section{Volume 6, Number 1, June 2020}

that hinder the achievement of it. These factors, when taken into serious consideration, would definitely create an effect on "student success" (Millea, et al., 2018). In the basic education sector, Ibrahim (2020) advocated that the number of teachers handling classes be increased since this was found out to have an "effect on early childhood development and education graduate rate."

Bahak, et al, (2017) evaluated Indonesia's Graduate Competency in Elementary School and found out that there is a serious need for stakeholders to "understand the essence of learning mastery and its correlation with standards" as these impact students' academic achievement and teachers" performance in the classroom. Similarly, "community violence" has been identified to be a social element of students' unfavourable academic performance (Bergen-Cico, et al., 2018). It is also interesting how Hughes, et al. (2018) noted that academic retention in the early grades contributes to greater possibilities of dropping out of school before graduation.

\section{METHOD}

This study employed qualitative method through content analysis using data available online. As a generally utilized approach, interpretation of meaning according to identified contexts of available data has been carefully executed. To be specific, this study involved summative content analysis following content or guide words (key words) which eventually led to the reading and understanding of essential and applicable setting. Graduation messages annually issued by the DepEd Secretary are posted and accessible through online resources. These were then downloaded by the researchers and filed in a database for extensive reading and analysis.

Graduation messages issued from 2010-2019 were utilized in this study. These were relayed by the DepEd to stakeholders in different levels of the basic education sector. The researchers believed that the period is sufficient enough to capture the essence of graduation messages and provide substantial data in the light of identified objectives of the study. While messages are available in English and Filipino, messages written in English were purposively chosen for the purpose of consistency and analysis.

After downloading each message, the researchers analysed the document vis-a-vis themes relayed which were then compared with other graduation addresses. The results of the initial analysis were then clustered into themes to draw inputs.

Since the study purely employed documentary data, no potential ethical risks to humans were encountered. The study posed no harm to humans. Ethical treatment of documentary data was observed by the researchers and analysis was conducted with outmost objectivity and fairness. 
Each graduation message was scrutinized only for the sole purpose of addressing established research inquiry of the research.

\section{RESULTS AND DISCUSSION}

This section presents the results of the researchers' thorough analysis of data gathered. Annual graduation messages are initially analysed vis-a-vis the graduation theme. The first part of the discussion focuses on each academic year's gist of graduation messages. The second part presents clustered themes generated from the first analysis.

In 2010, the graduation message revolved around the theme "Education: Changing Lives." Education is highlighted as the solution in facing life's challenges and in empowering the every Filipino citizen. More so, in the attainment of the positive changes, recognition goes to parents or people who supported the learners in their academic journey and towards the achievement of their goal. The following year, in 2011, the message shifted focus on the roles of graduates in advocating transformation and change. Positive difference simply comes from being aware of the family and the community to which one belongs and must be considered and recognized as significant because they sustain one's existence and the source of determination to help one's family and giving service to the community. More so it encompasses how education makes a person more capable in building a positive difference towards the betterment of the nation, in attaining great opportunities, and in making a transformational change. The theme for 2011 is "The Graduate: A Partner Towards Transformational Society, Response to Societal Change"

The year 2012 echoed the previous year's message as learning is referred to as an instrument towards societal and national growth. With the theme "Your Gift of Learning, Our Tool for Nation Building," the gift of learning emphasized is a universal one offered to every stakeholder in the education sector from which upholds the cultivated values, knowledge and skills earned through education as a product one's hardship, adversity life experiences strongly build and empower a nation. The dawn of the K-12 curriculum, in 2013, witnessed the rigorous educational transition and changes in the curriculum. The graduation message pointed to the development learner's capability and to the whole society in threading to the world's great opportunities. It emphasizes their role as the generation who will build a more progressive future for the nation. Graduation 2013's theme is "Building the Nation's Future Leaders Through the K to 12 Basic Education Program." 


\section{Volume 6, Number 1, June 2020}

After reflecting $\mathrm{n}$ what the country has gone through in times of disaster and devastation, with the theme "The Filipino Spirit Cannot Be Shaken", 2014 graduation message paid tribute to the resilience of the Filipino and its triumphs amidst the odds of the string of devastating calamities it conquered over the year. It emphasizes how education impacts the Filipino spirit in upholding great values in times of such occurrences, on towards overcoming the hardships and pains it brought. The graduation message in 2015 entails K to 12 Basic Education Program as an exemplar in transporting knowledge to the learners for national development. With the theme "Simple Life Shaped By Quality Education," it underscores how quality education leads to a better opportunity as it builds a great foundation towards a strong nation through the developed and harnessed skills and competencies drawn from the curriculum. The 2016 graduation message focuses on education as a continued cycle that keeps moving with different reforms, such as the implementation of the $\mathrm{K}$ to 12 Basic Education Program as a transformative vehicle for local and national development. The message, which carried the theme "K-12 Learners: Key to National Development" champions the K-12 curriculum which serves as a driver to develop and harnesses the skills and competencies as it transpire to attain a holistic development of the Filipino youth that will lead to human and community development.

With the theme "Hand in Hand Towards a Progressive Nation," 2017 graduation message focuses on the great role of the stakeholders and learners, with their joint efforts and sacrifices, in order to attain the shared vision of quality, accessible, timely, and liberating basic education for all. It gives significance to the value of unity and togetherness in education, in forgoing a better and progressive nation. The 2018 graduation message looks again at the curriculum and the changes brought by the K-12 education and the core values it upholds, strengthens the Filipino learners to cope up with the life challenges and global competitiveness. The theme for 2018 is $\mathrm{K}$ " $\mathrm{K}$ to 12 Learners: Ready to Face Life's Challenges." Lastly, in 2019, with K-12 already in place, the education program is seen as essential in achieving a holistically developed learners and society where people embrace the challenge and benefits of the nation's diverse roots, culture, and traditions and being united in achieving a better nation. The theme for this year is "Unity in Diversity: Quality Education for All”.

The promise of education is truly enticing and uplifting to everyone as education liberates one from any form of unevenness. Graduation holds a symbol of hope and new beginning and 
opens the threshold of new challenges, and roads of journey to tread on. The message given by the DepEd Secretary holds the hope and symbolism to inspire learners as they pursue a new chapter in their life.

\section{Quality Education as the Key To Transformation}

Different changes occur to every human each day. It is an essential part of every human experience in order to attain growth. Changes comes in different form, but more importantly it always come from the same person within.

The year 2010 marked a new milestone in the Philippine politics and to the whole nation as the national election will occur that time. The graduation message by then DepEd Sec. Jesli Lapus solidifies the importance of education as the solution in facing life's challenges and in empowering the citizen's nation. With graduation message highlights the hope of change that arises to every Filipinos heart as the outgoing administration is about to unfold. The biggest part of the change greatly impacts the education that we have, as the message underscores.

"Indeed, your education is the solution to the need to address your concerns as an individual as it is the solution to our problems as a society and as one nation." - Jesli A. Lapus, 2010 Message to Graduates

In the attainment of the positive changes, it will always come from the person themselves and these changes affect everything with the help of education. Having an education puts a person in secured place and future and a key to resolve the mediocrity. Thus, the nation will rise, depending on how a person accepts the changes.

Change is the same highlight in the 2015 message, with greater emphasis to the new curriculum; where in the $\mathrm{K}$ to 12 Basic Education Program is regarded as transporting vehicle of knowledge to the learners and for national development.

"For us in the schools, may this theme guide us all as we go forth and realize our mission to provide Filipino learners a quality education that will empower them to attain their life goals."-

Armin Luistro, 2015 Message to Graduates

Quality education is equated with better opportunity as it builds a great foundation towards a strong nation through the developed and harnessed skills and competencies drawn from the curriculum.

\section{Education at the Core of Life's Challenges}

It was in the school year 2013-2014 when the major calamities such as typhoon Haiyan or locally known as "Yolanda" devastated the most part of the Visayan region, particularly Samar 128 


\section{Volume 6, Number 1, June 2020}

and Leyte provinces. 2014 was then marked as the year of great calamities that happened in the past 10 years. The message for graduation 2014 gave tribute to the resiliency of the Filipino as they awake from the devastating events and its triumphs as they conquered over the school year.

"For us in the schools, may this theme remind us of the energy that should continue to animate our institutions which in turn would help us give to each of our learners the best that they deserve." Armin Luistro, 2014 Message to Graduates

In the message, it was also stressed how education impacts the Filipino spirit in upholding great values in times of such occurrences, on towards overcoming the hardships and pains it brought to the lives of many people. It is in this light that Filipinos are one, in every challenge and triumphs they experience.

\section{Filipino Learners Transforming the Future}

It is always a typical belief that the youth will be the imminent leaders of one's nation as the generation will be the ones to take over the future. Good leaders need a good and strong foundation to become the next promising leader. In 2011, DepEd Secretary Armin A. Luistro, in his message sees the graduates as partners towards transformational society, an answer to societal change and highlights making positive difference.

"..each of you is called to be more aware of the family you are in and the community where your family and school reside. Those are the worlds larger than your individual selves which you must consider as significant because they sustain your existence.” - Armin Luistro, 2011 Message to Graduates

More so, it encompasses how education makes a person more capable in building a positive difference towards the betterment of the nation, in attaining great opportunities, and in making a transformational change. In effect, its ideal form creates valuable and positive change in the followers with the end goal of developing the learners into leaders. Thus, it is imperative to uphold every learner as hope of the future.

Consequently, K-12 Basic Education Program was given emphasis in the 2016 graduation message. It says that its implementation transforms learners to attain local and national development. It arms the learners to develop and harnesses the skills and competencies as it transpires to attain a holistic development of the Filipino youth that will lead to human and community development.

The message in year 2018 sees changes brought by the K-12 education curriculum to the learners. With the emphasis on the 4 core values of DepEd, these taught the Filipino learners to 
uphold and strengthened them as they face life challenges and global competitiveness. Briones further mentioned, "Whatever path you will pursue after this momentous occasion, may you continue to uphold the core values of your alma mater and DepEd - Maka-Diyos, Maka-tao, Makakalikasan, and Makabansa (for God, people, nature, and country). Bear in mind that while education is your right, it also bestows upon you a greater responsibility to contribute to the betterment of our society."

Briones hoped that Filipino learners in the K-12 were equipped with the 21st century skills and lifelong competencies through the quality education it brought, that is accessible, relevant, and liberating for all.

\section{The Stakeholders and Learners Towards A Better Education}

The gift of learning is universal which covers every stakeholder in the education sector form, and it is limitless to what their status in life. In the 2013 graduation message, this gift of learning greatly upholds the cultivated values, knowledge and skills earned through education. The hardship and the adversity of life experiences strongly build and empower a nation. As Luistro mentioned, "The integrity we bring into our homes and classrooms become the foundation of our own future. The justice, peace and prosperity we yearn for strongly depend on the truth and faithfulness we invest today."

The role of the stakeholders and learners were highlighted as well in the year 2017 message along with their efforts and sacrifices, in attaining the shared vision of quality, accessible, timely, and liberating basic education for all. It pays tribute to their significant promotion of unity and togetherness in education that result to a more relevant and peaceful education access.

"Your mentors are confident that you will continue living up to become citizens of character and lofty ideals, and whose critical thinking and competency will take the country to path of global competitiveness and recognition."- Leonor Briones, 2017 Message to Graduates

It is in the hope that Filipino learners, through a better and unifying education, will grow to become good and a strong citizens to the nation.

\section{The K-12 Curriculum as the Vehicle for Success}

The K-12 law emanates a rigorous change in the landscape of the Philippine education system. It created an emblem of hope and progress to pattern in the international globalization and in the attainment of the 21 st century skills among the Filipino learners. The changes made in 


\section{Volume 6, Number 1, June 2020}

the curriculum and the education system brought drastic reactions, which is an essential part of undergoing transformations.

As the K-12 law was passed in the year 2013, the graduation message pointed out the rigorous educational transition and changes in the curriculum where the piloting of the new curriculum, K-12 Basic Education Program, is yet to succeed. The changes entirely see welfare for every learner in the development of the society and in threading to the world's great opportunities. In the message, learners under the K-12 curriculum are viewed as the generation who will build a more progressive future for the nation.

"The $K$ to 12 Basic Education program is a massive upgrade of lessons, subjects and methods to ensure we are honing your gifts to maximize your potential. You are at the heart of this upgrade. In helping you grow to be the persons you are meant to be, we are helping build the nation's future." - Armin Luistro, 2013 Message to Graduates

In 2019, DepEd Secretary Leonor Briones mentioned in her message that the quality education is adhered to all and that the K-12 program is one in achieving a holistically developed learners and society where people embrace the challenge and benefits of the nation's diverse roots, culture, and traditions and being united in achieving a better nation.

"Rest assured that through the K to 12 Basic Education Program, DepEd shall strive to hone our future leaders and nation-builders in a society that embraces diversity and all its challenges and advantages. I am positive that whatever path they wish to pursue hereafter, our graduates and completers will continuously enrich what makes up the Filipino soul-our culture, talent, history, and capacity to survive." Leonor Briones, 2019 Message to Graduates

Clustered themes reveal relevant issues discussed in the annual graduation messages. Each message recognizes the contribution of agents involved the education process: from students, teachers, parents, and other stakeholders. Social, cultural, and curricular aspects have also been identified as significant drivers that shape the education landscape in the Philippines.

\section{E. CONCLUSION}

Analysis of graduation messages issued by the DepEd presents a narrative worthy of inquiry and investigation. Results of the study serve as significant inputs to theorizing education practices and practicing education theories.

In the light of the established research inquiries, the following conclusions are offered. These concluding statements are informed by analysis and thorough scrutiny of the data. 
Annual graduation messages beyond words. With the following clustered themes: quality education as the key to transformation, education at the core of life's challenges, Filipino learners transforming the future, stakeholders and learners towards a better education, and K-12 curriculum as the vehicle for success, it could be noted that graduation messages have captured essential elements of the education system.

Stakeholders as frontrunners of academic success. Recognition has been given to stakeholders who play crucial roles in the education system and advocate its success. Also, social, cultural, and curricular aspects have also shaped how each graduation message is crafted and relayed to stakeholders.

Challenges, disaster, and hardships leading to graduation success. It is worthy to note how graduation messages made mention of natural and man-made catastrophes faced by the Filipino people. These events are seen as pressing incidents that shape the current education landscape in the country.

With the abovementioned conclusions, the study is also bounded by research limitations. The study only covered ten years of annual graduation messages. It is suggested that future researches involve a larger reach for depth and width. This will provide a more inclusive perspective, particularly in terms of temporal element. Also, it only reported messages issued by the DepEd. In the future, graduation messages issued by various offices and stakeholders could also provide meaningful analysis and inputs as looking at their messages would be noteworthy to consider.

\section{REFERENCES}

Anderson, J. (2018). Applying Speech Act to Regional Integration. Discussion Paper. www.shd.chiba .jp.glblcrss.Discussion_Papers/pdf/Applying_Speech_Act_Theoryh_an d Regional_Integration.pfd.

Arcidiacono, Peter, Esteban M. Aucejo, and V. Joseph Hotz. 2016. "University Differences in the Graduation of Minorities in STEM Fields: Evidence from California." American Economic Review, 106 (3): 525-62. DOI: 10.1257/aer.20130626

Bahak Udin, By Arifin, M., Rais, P., \& Nurdyansyah, N. (2017). An Evaluation of Graduate Competency in Elementary School.

Bromberg, M., \&Theokas, C. (2016). Meandering toward Graduation: Transcript Outcomes of 


\section{Volume 6, Number 1, June 2020}

High School Graduates.Education Trust.

Charmatz, M. (2019). Graduation ceremonies need to be accessible. Disability Compliance for Higher Education, 24(10), 1-3.

Fjær, E. G., Pedersen, W., \& Sandberg, S. (2016). Party on wheels: mobile party spaces in the Norwegian high school graduation celebration. The British Journal of Sociology, 67(2), 328-347.

García-Aracil, A., Monteiro, S., \& Almeida, L. S. (2018). Students’ perceptions of their preparedness for transition to work after graduation. Active Learning in Higher Education, 1469787418791026.

Hughes, J. N., West, S. G., Kim, H., \& Bauer, S. S. (2018). Effect of early grade retention on school completion: A prospective study. Journal of educational psychology, 110(7), 974.

Ibrahim, K. W. (2020). Effect of pupil-teacher ratio on graduation rate of early childhood development and education in Embu County public primary schools, Kenya. Journal of Pedagogy, Andragogy and Heutagogy in Academic Practice/ISSN: 2708-261X, 1(1), 18-21.

Lemkin, A., Kistin, C. J., Cabral, H. J., Aschengrau, A., \& Bair-Merritt, M. (2018). School connectedness and high school graduation among maltreated youth. Child abuse \& neglect, $75,130-138$.

Lomsky-Feder, E. (2012). High School Graduation Ceremonies: Intergenerational Relations and Models of Social Order.Social Analysis, 56(3), 49-68.

Millea, M., Wills, R., Elder, A., \& Molina, D. (2018). What matters in college student success? Determinants of college retention and graduation rates. Education, 138(4), 309-322.

Muir, R., \& Palmer, K. (2019).Perspectives on... graduation ceremonies.Every Child, 25(2), 6.

Robison, S., Jaggers, J., Rhodes, J., Blackmon, B. J., \& Church, W. (2017). Correlates of educational success: Predictors of school dropout and graduation for urban students in the Deep South. Children and Youth Services Review, 73, 37-46.

Roelen, K. (2020). Child-sensitive graduation: How can programmes break the intergenerational cycle of poverty?.Global Social Policy.

Rohmaniyah, I., \& Woodward, M. (2012).Wahhabism, Identity, and Secular Ritual: Graduation at an Indonesian High School. Al-Jami'ah: Journal of Islamic Studies, 50(1), 119-145. 
Rodenbusch, S. E., Hernandez, P. R., Simmons, S. L., \& Dolan, E. L. (2016). Early engagement in course-based research increases graduation rates and completion of science, engineering, and mathematics degrees. CBE_Life Sciences Education, 15(2), ar20.

Sublett, C., \& Rumberger, R. (2018). What is California's High School Graduation Rate?

Wills, T. W., Wolford, T. E., \& Goldberg, A. (2017). Effects of Career and Technical Education on Graduation Rates: A Longitudinal Study from the School District of Philadelphia. AERA Online Paper Repository.

Zaff, J. F., Donlan, A., Gunning, A., Anderson, S. E., McDermott, E., \&Sedaca, M. (2017). Factors that promote high school graduation: A review of the literature. Educational Psychology Review, 29(3), 447-476. 